\title{
Impaired Cell Membrane Integrity
}

National Cancer Institute

\section{Source}

National Cancer Institute. Impaired Cell Membrane Integrity. NCI Thesaurus. Code C40793.

Impaired Cell Membrane Integrity consists of activities that interfere with, or restrain, fabrication, construction, or maintenance of the regular structure and function of semipermeable lipid bilayer membranes that surround or reside within a cell. 